\title{
PERILAKU EKSPOR PERUSAHAAN MANUFAKTUR DI INDONESIA, 1990-2000
}

\author{
Sahminan ${ }^{1}$ and Yati Kurniati ${ }^{2}$
}

\begin{abstract}
This paper examines export behaviour of manufacturing firms in Indonesia. We use firm-level data from survey of medium and large Indonesian manufacturing industries over the period 1990-2000. Using panel data regression technique, we find the following regularities. First, there is a persistency in the firm's decision to export as well as proportion of exported output. Second, higher wage, larger number of production employment, higher productivity and higher share of foreign ownership lead to higher probability of a firm to export. Third, higher wage leads to higher proportion of exported output. However, higher productivity or higher share of foreign ownership leads to lower proportion of exported output. Fourth, while real exchange rate does not significantly affect the probability of firms to export, it significantly affects the proportion of exported output. Fifth, both probability to export and proportion of exported output was significantly much lower during the 1997/1998's Asian crisis. Finally, looking at the export behaviour across industries, the estimation results show that there is a variation of export behaviour across industries.
\end{abstract}

Keywords: Export, manufacture, Indonesia.

JEL Classification: F14, F13, D21

1 Directorate of Economic Research and Monetary Policy, Bank Indonesia, sahminan@bi.go.id

2 Directorate of Economic Research and Monetary Policy, Bank Indonesia, yati_k@bi.go.id

We would like to thank comments from Dr. Perry Warjiyo, Dr. Iskandar Simorangkir, Dr. Ari Kuncoro, and other participants in a conference sponsored by Directorate of Economic Research and Monetary Policy, Bank Indonesia. The views expressed herein are those of the authors and do not necessarily those of Bank Indonesia. 


\section{PENDAHULUAN}

Mempromosikan ekspor adalah salah satu agenda utama dari kebijakan ekonomi Indonesia, dan juga salah satu agenda utama dari negara-negara berkembang lainnya. Selama periode 1990-2007, ekspor industri manufaktur Indonesia meningkat dari 37 persen menjadi 46 persen. Namun demikian, dibandingkan dengan negara-negara lain di wilayah ini, ekspor industri manufaktur Indonesia masih jauh tertinggal. Ekspor industri manufaktur di Malaysia dan Thailand pada tahun 2007, misalnya, masing-masing mencapai 72 persen dan 77 persen.

Ada sejumlah alasan mengapa ekspor manufaktur sangat bernilai tinggi di negara-negara berkembang (Das, Roberts, dan Tybout, 2001). Pertama, ekspor industri membantu perolehan keuntungan perdagangan melalui dampak keunggulan komparatif dan alokasi sumber daya intra-industri. Kedua, pasar produk-produk industri sangat beraneka ragam, dan memiliki posisi yang baik untuk bisa menjaga tingkat produksi dan lapangan pekerjaan ketika terjadi resesi domestik. Ketiga, perusahaan-perusahaan ekspor bisa memfasilitasi penyerapan teknologi.

Dengan melihat manfaat yang diperoleh dari ekspor manufaktur, banyak negara berusaha mendorong ekspor melalui berbagai faktor yang dianggap memiliki dampak positif terhadap ekspor manufaktur. Oleh karenanya, penting untuk memaparkan faktor-faktor utama yang membantu ekspor manufaktur. Meskipun secara teoritis ada sejumlah faktor yang bisa menjelaskan faktor-faktor yang berpotensi meningkatkan ekspor, namun masih kurang pemahaman tentang mengapa beberapa perusahaan melakukan ekspor sementara yang lainnya tidak. Sejauh ini, sebagian besar studi tentang ekspor Indonesia dilakukan pada tingkat negara atau industri, yakni, studi tentang faktor-faktor yang menentukan ekspor dan impor Indonesia sebagian besar dilakukan pada tingkat agregat.

Tujuan dari makalah ini adalah untuk memberikan bukti-bukti empiris tentang faktorfaktor yang menentukan keputusan ekspor oleh perusahaan-perusahaan di Indonesia. Selain itu, makalah ini juga memaparkan bukti empiris tentang faktor-faktor yang menentukan peningkatan atau penurunan proporsi output yang diekspor dari perusahaan-perusahaan manufaktur di Indonesia. Diharapkan makalah ini bisa memberi pengetahuan tentang berbagai faktor yang berkontribusi dalam pembuatan keputusan perusahaan manufaktur untuk melakukan ekspor. Hasil dari makalah ini akan memberikan pemahaman yang lebih baik tentang penyebab ekspor di sektor manufaktur di Indonesia yang kemudian bisa digunakan sebagai landasan untuk membuat kebijakan untuk memajukan ekspor Indonesia.

Susunan makalah adalah sebagai berikut. Bagian II memaparkan tinjauan literatur. Bagian III membahas model teoritis dari keputusan perusahaan untuk melakukan ekspor. Bagian IV memaparkan metodologi empiris. Bagian $\vee$ berisi penjelasan tentang perusahaan-perusahaan 
manufaktur di Indonesia. Bagian VI berisi hasil estimasi. Terakhir, makalah ini akan disimpulkan pada Bagian VII.

\section{TINJAUAN LITERATUR}

Sejumlah makalah telah melakukan studi empiris tentang faktor-faktor yang mendorong perusahaan untuk berekspor. Alvarez dan Lopez (2008) mengkaji faktor penentu ekspor masuk dan keluar dari perusahaan-perusahaan manufaktur Chili. Mereka menemukan bahwa heterogenitas industri - seperti produktivitas dan karakteristik perusahaan - berdampak signifikan pada perputaran pabrik (plant turnover) di pasar internasional. Di sisi lain, biaya dagang, intensitas faktor dan fluktuasi nilai tukar riil hanya berperan kecil. Bernard dan Jensen (2001) mengkaji faktor penentu keputusan ekspor yang dibuat oleh perusahaan manufaktur AS. Mereka menemukan bahwa karakteristik pabrik - terutama aktivitas ekspor perusahaan di masa lalu dan nilai tukar yang menguntungkan sangat meningkatkan probabilitas perusahaan untuk melakukan ekspor. Sementara itu, limpahan aktivitas ekonomi (spill-over) dari aktivitas ekspor pabrik lain dan pengeluaran pemerintah untuk promosi ekspor tidak berdampak signifikan terhadap probabilitas ekspor.

Castellani et al (2007) mengkaji hubungan antara ekspor dan produktivitas di 14 negara. Bukti-bukti yang mereka peroleh mendukung hipotesis bahwa perusahaan-perusahaan eksportir cenderung lebih produktif dibandingkan perusahaan-perusahaan non-eksportir, dan ada bukti kuat tentang swaseleksi (self-selection) dari perusahaan-perusahaan yang lebih produktif untuk masuk ke dalam pasar ekspor. Akan tetapi, hipotesis bahwa limpahan (spill-over) pengetahuan dari pembeli dan pesaing internasional membantu meningkatkan kinerja eksportir tidak didukung oleh studi mereka. Studi ini nampaknya mempertegas hasil survei literatur yang dilakukan Wagner (2007), dimana dia juga menemukan bahwa eksportir adalah perusahaan-perusahaan yang lebih produktif dan melakukan swaseleksi (self-select) untuk masuk ke pasar ekspor sementara arah sebaliknya - bahwa aktivitas ekspor menaikkan produktivitas - tidak selalu terjadi.

Aitken, Hanson, dan Harrison (1997) menyelidiki apakah eksportir-eksportir lain meningkatkan probabilitas non-eksportir untuk menjadi perusahaan eksportir. Dengan kata lain, mereka mengkaji efek limpahan aktivitas ekonomi (spill-over effect) dari perusahaan eksportir pada perusahaan-perusahaan lain. Dengan menggunakan data perusahaan manufaktur di Meksiko, mereka menemukan bahwa probabilitas perusahaan manufaktur untuk melakukan ekspor meningkat jika perusahaan tersebut berlokasi di dekat perusahaan multinasional. Dengan kata lain, aktivitas eksportir domestik tidak berdampak signifikan pada probabilitas perusahaanperusahaan lain untuk melakukan ekspor. Mereka mengemukakan bahwa alasan dari temuan 
ini adalah bahwa perusahaan multinasional asing memberikan saluran dimana perusahaanperusahaan domestik bisa mendapatkan informasi tentang pasar dan teknologi asing. Selain itu, informasi dan layanan distribusi yang disediakan oleh investor asing bisa meningkatkan prospek ekspor dari perusahaan lokal.

Arnold dan Hussinger (2005) menganalisa hubungan kausalitas antara produktivitas dan ekspor dari perusahaan manufaktur Jerman. Hasil temuan mereka menunjukkan bahwa produktivitas yang lebih tinggi menyebabkan masuknya perusahaan ke pasar asing, dan tidak ada bukti bahwa keberadaan di pasar internasional akan menyebabkan peningkatan produktivitas. Dengan demikian, studi ini menunjukkan bahwa perusahaan-perusahaan manufaktur Jerman yang memiliki produktivitas tinggi cenderung melakukan swaseleksi (selfselect) untuk masuk ke pasar ekspor.

\section{KERANGKA TEORITIS}

Menurut Bernard dan Jensen (2004), landasan teoritis dari keputusan untuk melakukan ekspor yang dibuat oleh perusahaan manufaktur bisa dimodelkan dengan menggunakan perusahaan rasional yang memaksimalkan keuntungan. Untuk tiap periode $t$, masing-masing perusahaan $i$ diasumsikan memproduksi jumlah ekspor optimal $q^{*}{ }_{i t}$ pada harga $p_{t}$ dengan fungsi keuntungan:

$$
\pi_{i t}\left(X_{i t}, Z_{t}\right)=p_{t} q_{i t}^{*}-c_{i t}\left(X_{i t}, Z_{t} \mid q_{i t}^{*}\right)
$$

dimana $c_{i t}(\cdot)$ adalah variabel biaya untuk memproduki jumlah ekspor, $q^{*}{ }_{i t}, X_{i t}$ adalah vektor dari faktor spesifik perusahaan dan $Z_{t}$ adalah vektor faktors eksogen yang mempengaruhi profitabilitas perusahaan.

$Y_{i t}$ adalah status ekspor perusahaan $i$ pada periode $t$ yang ditentukan oleh keuntungan yang diharapkan perusahaan, yakni:

$$
Y_{i t}=\left\{\begin{array}{lll}
1 & \text { if } & \pi_{i t}\left(X_{i t}, Z_{t}\right) \geq c_{i t} \\
0 & \text { if } & \pi_{i t}\left(X_{i t}, Z_{t}\right)<0
\end{array}\right.
$$

Persamaan (V.2) menyatakan bahwa suatu perusahaan akan melakukan ekspor jika keuntungan yang diharapkan dari ekspor lebih besar dari atau sama dengan nol. Dengan adanya biaya masuk (entry cost) untuk melakukan ekspor, maka fungsi keuntungan bisa dirumuskan sebagai berikut: 


$$
\tilde{\pi}_{i t}\left(X_{i t}, Z_{t}\right)=p_{t} q_{i t}^{*}-c_{i t}\left(X_{i t}, Z_{t} \mid q_{i t}^{*}\right)-\eta\left(1-Y_{i t-1}\right)
$$

dimana $\eta$ adalah biaya masuk untuk ekspor.

Dengan memperluas persamaan ke masalah keputusan pada model satu-periode menjadi model multi-periode (multiple-period), maka keputusan untuk melakukan ekspor bisa dirumuskan sebagai berikut. Dalam model multi-periode, keuntungan yang diharapkan perusahaan dihitung dengan persamaan:

$$
\Pi_{i t}\left(X_{t}, Z_{i t}\right)=E_{t}\left(\sum_{s=t}^{\infty} \delta^{s-t}\left[\tilde{\pi} . Y_{i s}\right]\right)
$$

Jika jumlah ekspor hari ini mempengaruhi biaya ekspor besok, yakni, jika $\frac{\partial c_{i t}(.)}{\partial q_{i t-1}^{*}} \neq 0$, maka status ekspor besok dipengaruhi oleh status ekspor hari ini. Karenanya, masalah perusahaan adalah masalah pemprograman dinamis dengan fungsi nilai yang diberikan oleh:

$$
V_{i t}(\cdot)=\max _{\left\{q_{i t}\right\}}\left(\pi_{i t} \cdot\left[q_{i t}^{*}>0\right]+\delta E_{t}\left[V_{i t+1}(\cdot) \mid q_{i t}^{*}\right]\right)
$$

Suatu perusahaan akan memilih untuk berekspor pada periode $t$ jika fungsi nilai ekspor lebih besar dibandingkan fungsi nilai tidak melakukan ekspor, yakni,

$$
\begin{aligned}
& V_{i t}\left(q_{i t}^{*}>0\right)>V_{i t}\left(q_{i t}^{*}=0\right) \\
& \tilde{\pi}_{i t}+\delta E_{t}\left[V_{i t+1}(\cdot) \mid q_{i t}^{*}>0\right]>\delta E_{t}\left[V_{i t+1}(\cdot) \mid q_{i t}^{*}=0\right] \\
& p_{t} q_{i t}^{*}+\delta E_{t}\left[V_{i t+1}(\cdot) \mid q_{i t}^{*}>0\right]-\delta E_{t}\left[V_{i t+1}(\cdot) \mid q_{i t}^{*}=0\right]>c_{i t}+\eta \cdot\left(1-Y_{i t-1}\right)
\end{aligned}
$$

Pada model multi-periode ini, biaya masuk terlihat dari kaitan antara aktivitas ekspor selama dua tahun berturut-turut. Karenanya, keberadaan inter-temporal spill-over diasumsikan disebabkan oleh adanya biaya masuk. 


\section{METODOLOGI}

\section{IV.1 Model Empiris}

Berdasarkan pada model multi-periode, sebagaimana diberikan dalam persamaan (V.8), model empiris untuk mengetahui keputusan perusahaan untuk melakukan ekspor bisa dirumuskan sebagai berikut:

$$
Y_{i t}=\left\{\begin{array}{ccc}
1 & \text { if } & \bar{\pi}_{i t}>c_{i t}-\eta\left(1-Y_{i t-1}\right) \\
0 & \text { otherwise }
\end{array}\right.
$$

dimana

$$
\bar{\pi}_{i t}=p_{t} q_{i t}^{*}+\delta\left(E_{t}\left[V_{i t+1}(\cdot) \mid q_{i t}^{*}>0\right]-E_{t}\left[V_{i t+1}(\cdot) \mid q_{i t}^{*}=0\right]\right)
$$

Untuk memperkirakan keputusan perusahaan untuk melakukan ekspor, kami menggunakan persamaan (V.9) dengan model empiris struktural non-biner:

$$
Y_{i t}=\left\{\begin{array}{ccc}
1 & \text { if } & \beta X_{i t}+\gamma Z_{t}+\varepsilon_{i t}>0 \\
0 & \text { otherwise }
\end{array}\right.
$$

dimana $X_{i t}$ adalah vektor karakteristik perusahaan, dan $Z_{t}$ adalah vektor faktor eksogen.

Persamaan (V.11) bisa diperkirakan dengan menggunakan kerangka pilihan biner dinamis (dynamic binary choice framework) dengan heterogenitas yang tidak diamati (unobserved heterogeneity), seperti model probabilitas linier, model probit, atau model logit kondisional.

Salah satu masalah utama dalam memperkirakan model ini adalah menentukan apakah heterogenitas perusahaan yang tidak diamati akan lebih baik jika dimodelkan menggunakan efek acak (random effect) atau efek tetap (fixed effect). Jika efek perusahaan tidak berkaitan dengan regresor maka model efek acak (random effect) lebih sesuai digunakan. Di sisi lain, pada tipe model ini, model efek tetap (most fixed effect) menghasilkan estimasi yang bias dan tidak konsisten, terutama estimasi tentang variabel beda kala (lagged dependent variable) (Bernard dan Jensen, 2004). Untuk mengatasi masalah endogenitas kami menggunakan variabel lagged explanatory.

Sebagaimana disebutkan di awal, selain mengkaji faktor-faktor yang menentukan keputusan suatu perusahaan untuk melakukan ekspor, kami juga mengkaji faktor-faktor yang menentukan proporsi output yang diekspor. Untuk melakukannya, kami memperkirakan model regresi linear panel yang dirumuskan sebagai berikut: 


$$
E X_{i t}=\alpha_{0}+\beta X_{i t}+\gamma Z_{t}
$$

dimana $E X_{i t}$ adalah proporsi output yang diekspor oleh perusahaan i pada tahun $t, X_{i t}$ adalah vektor karakteristik perusahaan, dan $Z_{t}$ adalah vektor faktor eksogen.

\section{IV.2. Variabel}

Untuk mengetahui sumber-sumber perbedaan dalam status ekspor kami menggunakan variabel spesifik perusahaan berikut ini. Lag aktivitas ekspor digunakan untuk mengetahui persistensi aktivitas ekspor suatu perusahaan. Perusahaan eksportir pada periode tertentu diperkirakan akan dipengaruhi oleh aktivitas ekspor sebelumnya. Meskipun variabel ini tidak bisa membedakan antara biaya masuk dan pengalaman ekspor, namun variabel ini bisa digunakan sebagai proxy untuk sunk cost (biaya yang tidak bisa diperoleh kembali) yang ditanggung perusahaan untuk masuk ke pasar ekspor.

Gaji bisa digunakan untuk mengetahui kualitas tenaga kerja, yang diharapkan berhubungan positif dengan masuk ke pasar ekspor dengan syarat bahwa barang yang diekspor memiliki kualitas yang lebih tinggi (Bernard \& Jensen 2001). Gaji juga bisa digunakan untuk mengetahui perbedaan harga-harga produk, karena kualitas tenaga kerja yang lebih baik cenderung memproduksi barang dengan kualitas yang lebih baik dan harga lebih mahal. Karenanya, kami memperkirakan bahwa gaji yang lebih tinggi cenderung menyebabkan probabilitas ekspor yang lebih tinggi.

Jumlah pegawai produksi digunakan untuk mengetahui besarnya (ukuran) perusahaan. Dalam industri manufaktur, ukuran perusahaan biasanya mengacu pada jumlah pegawai produksi dan bukannya nilai dari total output. Kami memperkirakan bahwa perusahaan yang memiliki pegawai produksi dalam jumlah besar cenderung memiliki probabilitas ekspor yang lebih tinggi. Untuk mengukur produktivitas pegawai, kami menggunakan nilai tambah per pegawai. ${ }^{3}$ Kami memperkirakan bahwa perusahaan yang memiliki produktivitas lebih tinggi memiliki kecenderungan lebih tinggi untuk melakukan ekspor.

Kepemilikan saham asing digunakan untuk mengetahui peran kepemilikan saham asing dalam aktivitas ekspor perusahaan. Suatu perusahaan dengan kepemilikan saham asing yang tinggi cenderung melakukan ekspor jika keberadaan investor asing dimaksudkan untuk mendapatkan biaya input yang lebih rendah. Di sisi lain, jika keberadaan investor asing adalah

3 Berdasarkan pada Bernard dan Wagner (1998). 
untuk masuk ke pasar domestik, maka kepemilikan saham asing yang semakin tinggi akan cenderung akan menurunkan probabilitas ekspor.

Selain dari variabel-variabel spesifik perusahaan yang telah disebutkan sebelumnya, kami juga melihat dampak faktor eksogen pada status ekspor perusahaan. Di sini, untuk mengendalikan faktor eksogen dan dampak krisis Asia tahun 1997/1998, kami menggunakan nilai tukar efektif riil dan dummy untuk krisis. Apresiasi nilai tukar efektif riil diperkirakan akan menurunkan probabilitas perusahaan untuk melakukan ekspor karena menurunnya daya saing. Di sisi lain, depresiasi nilai tukar efektif riil diperkirakan meningkatkan probabilitas perusahaan untuk melakukan ekspor karena peningkatan daya saing perusahaan. Karena berbagai hambatan yang dihadapi perusahaan pada saat krisis, kami memperkirakan bahwa probabilitas perusahaan untuk melakukan ekspor dan proposi output yang diekspor akan lebih rendah pada masa krisis.

\section{DATA DAN STATISTIK DESKRIPTIF}

Data tingkat perusahaan yang digunakan dalam studi ini diperoleh dari survei pada perusahaan-perusahaan manufaktur menengah dan besar di Indonesia. ${ }^{4}$ Data ini mencakup periode dari tahun 1990 sampai 2000 dengan frekuensi tahunan. Tiap tahun Badan Pusat Statistik (BPS) melakukan survei pada perusahaan manufaktur menengah dan besar. BPS mengirimkan kuesioner ke semua perusahaan manufaktur menengah dan besar yang tercatat dalam Direktori Perusahaan BPS yang diperbaharui tiap tahunnya. Berdasarkan atas produk utamanya, tiap perusahaan diklasifikasi ke dalam International Standard Industrial Classification of All Economic Activities (ISIC). Dalam data ini, perusahaan manufaktur mengacu pada unit produksi yang terletak di suatu bangunan atau gedung tertentu di bawah unit manajemen.

Selama periode 1990-2000, rata-rata 15 persen perusahaan manufaktur menengah dan besar di Indonesia melakukan ekspor (Tabel V.1 dan Grafik V.1). Pada periode krisis, jumlah perusahaan yang melakukan ekspor turun drastis, dan jumlah terendah tercatat pada tahun 1998 dimana hanya 2,3 persen perusahaan yang melakukan ekspor. Serupa dengan itu, proporsi output yang diekspor juga turun drastis dari sekitar 12 persen menjadi 2 persen (Grafik V.2).

4 Perusahaan manufaktur menengah dan besar adalah perusahaan manufaktur yang mempekerjakan 20 pegawai atau lebih 


\section{Tabel V.1}

Sebaran Perusahaan berdasarkan Aktivitas Ekspor, 1990-2000

\begin{tabular}{c|c|c|c} 
Tahun & Jumlah Perusahaan & Non Eksportir (\%) & Eksportir (\%) \\
1990 & 16.536 & 88,3 & 11,7 \\
1991 & 16.494 & 84,9 & 15,1 \\
1992 & 17.648 & 82,4 & 17,6 \\
1993 & 18.163 & 82,3 & 17,7 \\
1994 & 19.017 & 82,2 & 17,8 \\
1995 & 21.551 & 83,2 & 16,8 \\
1996 & 22.997 & 81,1 & 18,9 \\
1997 & 22.386 & 86,3 & 13,7 \\
1998 & 21.423 & 97,7 & 2,3 \\
1999 & 22.070 & 86,3 & 13,7 \\
2000 & 22.174 & 83,4 & 16,6 \\
& & &
\end{tabular}

(\%)

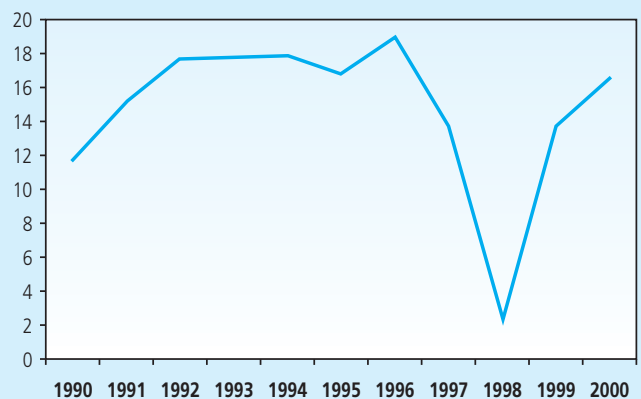

Gambar V.1

Sebaran Perusahaan

berdasarkan Aktivitas Ekspor

(\%)

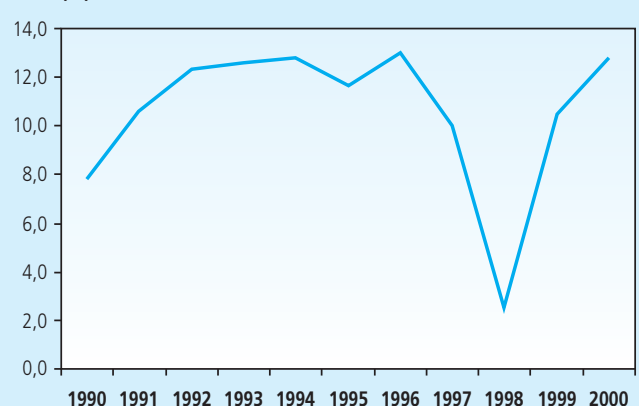

Gambar V.2

Proporsi Output yang Diekspor 
Jika kita melihat status perusahaan, 45 persen perusahaan PMA melakukan ekspor sementara hanya 28 persen perusahaan PMDN yang melakukan ekspor (Tabel V.2). Dan jumlah perusahaan eksportir yang melakukan impor juga lebih besar dibandingkan jumlah perusahaan non-eksportir yang melakukan impor (Tabel V.3).

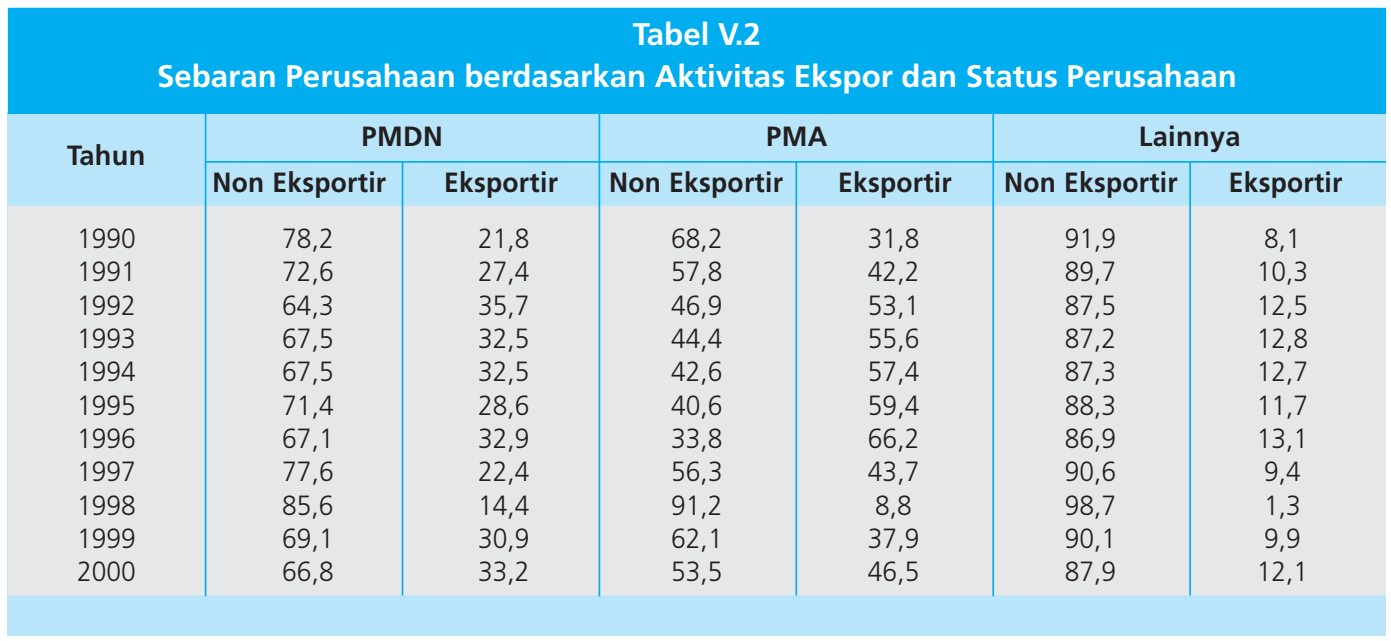

\section{Tabel V.3}

\section{Sebaran Perusahaan berdasarkan Industri dan Aktivitas Ekspor di tahun 2000}

\section{Industri}

Makanan, minuman dan tembakau

Tekstil, garmen dan kulit

Kayu, bambu, rotan, willow termasuk perabotan Kertas dan produk kertas, percetakan dan publikasi Produk kimia, minyak, batubara, karet dan plastik Produk mineral non-logam, non-minyak, non-batubara Logam dasar

Produk logam buatan, mesin dan perlengkapan Industri manufaktur lain

\begin{tabular}{c|c} 
Non Eksportir & Eksportir \\
90,4 & 9,6 \\
82,8 & 17,2 \\
62,4 & 37,6 \\
94,7 & 5,3 \\
83,7 & 16,3 \\
93,6 & 6,4 \\
81,7 & 18,3 \\
86,0 & 14,0 \\
71,3 & 28,7 \\
\end{tabular}

Berdasarkan atas klasifikasi industri, industri bambu, rotan, dan perabotan memiliki jumlah perusahaan terbanyak yang melakukan ekspor (Tabel V.4). Sekitar 38 persen perusahaan yang memproduksi kayu, bambu, dan perabotan mengekspor beberapa produk mereka. Ini menunjukkan bahwa perusahaan manufaktur di Indonesia yang melakukan ekspor terkonsentrasi pada industri berbasis sumber daya alam. 
Table V.4

Sebaran Perusahaan berdasarkan Aktivitas Ekspor dan Impor

\begin{tabular}{|c|c|c|c|c}
\multirow{2}{*}{ Tahun } & \multicolumn{2}{|c|}{ Non Eksportir } & \multicolumn{2}{c}{ Eksportir } \\
\cline { 2 - 4 } & Non Importir & Importir & Non Importir & Importir \\
1990 & 79,1 & 20,9 & 66,0 & 34,0 \\
1991 & 79,6 & 20,4 & 63,9 & 36,1 \\
1992 & 81,2 & 18,8 & 63,9 & 36,1 \\
1993 & 81,7 & 18,3 & 65,5 & 34,5 \\
1994 & 83,2 & 16,8 & 65,5 & 34,5 \\
1995 & 85,7 & 14,3 & 64,4 & 35,6 \\
1996 & 87,4 & 12,6 & 64,4 & 35,6 \\
1997 & 84,1 & 15,9 & 63,7 & 36,3 \\
1998 & 81,9 & 18,1 & 50,8 & 49,2 \\
1999 & 83,2 & 16,8 & 66,1 & 33,9 \\
\hline
\end{tabular}

Lebih dari 60 persen perusahaan eksportir pada tahun tertentu juga melakukan ekspor pada tahun sebelumnya. Dan lebih dari 70 persen perusahaan eksportir pada tahun tertentu sudah melakukan ekspor setidaknya sekali pada tahun sebelumnya (Tabel V.5).

\begin{tabular}{|c|c|c|}
\hline \multirow{3}{*}{ Tahun } & $\begin{array}{c}\text { Table V.5 } \\
\text { Eksportir berdasark }\end{array}$ & $\operatorname{Ian} \mathrm{E}$ \\
\hline & \multicolumn{2}{|c|}{ Eksportir $(\mathrm{t}, \mathrm{t}-1)$} \\
\hline & (Jumlah Perusahaan) & $(\%)$ \\
\hline $\begin{array}{l}1991 \\
1992 \\
1993 \\
1994 \\
1995 \\
1996 \\
1997 \\
1998 \\
1999 \\
2000\end{array}$ & $\begin{array}{c}1289 \\
1755 \\
2183 \\
2211 \\
2460 \\
2828 \\
2100 \\
500 \\
63 \\
2421\end{array}$ & $\begin{array}{c}51,7 \\
56,4 \\
67,8 \\
65,2 \\
67,9 \\
64,9 \\
68,6 \\
100,0 \\
2,1 \\
65,9\end{array}$ \\
\hline
\end{tabular}




\section{HASIL DAN ANALISA}

\section{VI.1 Keputusan untuk Melakukan Ekspor}

Hasil estimasi menunjukkan bahwa semua variabel spesifik perusahaan berdampak signifikan pada keputusan perusahaan untuk melakukan ekspor (Tabel V.6). Pertama, probabilitas suatu perusahaan untuk melakukan ekspor pada tahun tertentu sangat dipengaruhi oleh status ekspor perusahaan pada tahun sebelumnya. Perusahaan yang melakukan ekspor pada tahun tertentu memiliki probabilitas lebih tinggi untuk melakukan ekspor pada tahun berikutnya dengan nilai 0,303. Tingkat persistensi ini lebih besar dibandingkan tingkat persistensi ekspor industri manufaktur AS yang ditemukan oleh Bernard dan Jensen (2001), yakni 0,203.

Kedua, perusahaan dengan gaji yang lebih besar, jumlah pegawai produksi yang lebih banyak, produktivitas yang lebih tinggi, dan kepemilikan saham asing yang lebih tinggi sangat cenderung untuk memiliki probabilitas ekspor lebih tinggi, meskipun besarnya dampak gaji sangat kecil, yakni, kurang dari 1 persen. Dampak marjinal dari jumlah pegawai produksi, produktivitas dan kepemilikan saham asing terhadap probabilitas ekspor masing-masing adalah $0,028,0,012$ dan 0,083.

Terakhir, meskipun tandanya benar, namun nilai tukar riil tidak berdampak signifikan pada keputusan perusahaan untuk melakukan ekspor. Sementara itu, pada periode krisis Asia 1997/1998, probabilitas perusahaan untuk melakukan ekspor turun secara signifikan. Pada tahun 1998, probabilitas perusahaan untuk melakukan ekspor turun 6,7 persen.

Jika kita melihat perilaku ekspor dalam industri pada ISIC dua digit, hasil estimasi menunjukkan sejumlah keteraturan (regularity) (Tabel V.6 \& V.7). Pertama, semua industri menunjukkan persistensi signifikan dalam keputusan untuk melakukan ekspor, dimana industri kayu, bambu, rotan, dan perabotan memiliki persistensi tertinggi sementara industri tektil, garmen dan kulit memiliki persistensi terendah.

Kedua, semua industri menunjukkan bahwa kepemilikan saham asing yang lebih tinggi menyebabkan probabilitas ekspor yang lebih tinggi pula. Ketiga, kecuali pada industri logam dasar dan industri lain, produktivitas yang lebih tinggi berdampak signifikan terhadap probabilitas perusahaan untuk melakukan ekspor, dimana dampaknya positif sebagaimana yang diperkirakan. Keempat, meskipun di sebagian besar industri, gaji memiliki dampak positif, namun dampaknya sangat negatif dalam industri kayu, bambu, rotan dan perabotan. Kelima, jumlah pegawai produksi hanya berdampak signifikan terhadap probabilitas ekspor bagi industri logam dan mesin, dimana dampaknya positif. 
Keenam, nilai tukar riil hanya berdampak signifikan terhadap probabilitas ekpor dalam industri makanan dan tekstil. Akan tetapi, meskipun nilai tukar riil berdampak negatif terhadap industri tektil, sebagaimana yang diperkirakan, namun dampak nilai tukar riil terhadap keputusan ekspor dalam industri makanan adalah positif, yang artinya apresiasi nilai tukar riil menyebabkan peningkatan ekspor meskipun jumlahnya sangat sedikit. Terakhir, probabilitas perusahaan untuk melakukan ekspor di semua industri turun signifikan pada periode krisis Asia 1997/1998.

\begin{tabular}{|c|c|c|c|c|c|c|c|c|c|c|}
\hline \multicolumn{11}{|c|}{$\begin{array}{c}\text { Tabel V.6 } \\
\text { Dampak Marjinal dari Variabel Penjelas (Explanatory Variable) } \\
\text { terhadap Keputusan untuk Melakukan Ekspor }\end{array}$} \\
\hline & \multirow{2}{*}{ ALL } & \multicolumn{9}{|c|}{ ISIC } \\
\hline & & 31 & 32 & 33 & 34 & 35 & 36 & 37 & 38 & 39 \\
\hline Exported last year & $\begin{array}{r}0,3027 * * * \\
0,0078\end{array}$ & $\begin{array}{r}0,1271^{* * *} \\
0,0143\end{array}$ & $\begin{array}{r}0,0352 * * * \\
0,0144\end{array}$ & $\begin{array}{r}0,4944^{* * *} \\
0,0117\end{array}$ & $\begin{array}{r}0,0743 * * * \\
0,0269\end{array}$ & $\begin{array}{r}0,2447 * * * \\
0,0195\end{array}$ & $\begin{array}{r}0,0990 * * * \\
0,0259\end{array}$ & $\begin{array}{r}0,3536 * * * \\
0,0498\end{array}$ & $\begin{array}{r}0,3792^{* * *} \\
0,0226\end{array}$ & $\begin{array}{r}0,4357^{* * *} \\
0,0389\end{array}$ \\
\hline Wage & $\begin{array}{r}0,0002^{* * *} \\
0,0005\end{array}$ & $\begin{array}{r}0,0016^{* * *} \\
0,0040\end{array}$ & $\begin{array}{r}0,0039 * * * \\
0,0014\end{array}$ & $\begin{array}{r}-0,0177^{* * *} \\
0,0034\end{array}$ & $\begin{array}{l}0,0005 \\
0,0006\end{array}$ & $\begin{array}{r}0,0077 * * * \\
0,0017\end{array}$ & $\begin{array}{r}0,0013^{* * *} \\
0,0004\end{array}$ & $\begin{array}{l}0,0143 \\
0,0104\end{array}$ & $\begin{array}{r}0,0044^{* * *} \\
0,0017\end{array}$ & $\begin{array}{r}-0,0074 \\
0,0071\end{array}$ \\
\hline Production Employment & $\begin{array}{r}0,0286^{* * *} \\
0,0041\end{array}$ & $\begin{array}{r}-0,0039 * \\
0,0022\end{array}$ & $\begin{array}{r}-0,0010 \\
0,0156\end{array}$ & $\begin{array}{l}0,2258 \\
0,0347\end{array}$ & $\begin{array}{l}0,0063 \\
0,0047\end{array}$ & $\begin{array}{r}-0,0013 \\
0,0099\end{array}$ & $\begin{array}{r}-0,0050^{*} \\
0,0032\end{array}$ & $\begin{array}{r}0,1700^{* *} \\
0,0738\end{array}$ & $\begin{array}{r}0,0348^{* * *} \\
0,0136\end{array}$ & $\begin{array}{l}0,0900 \\
0,0719\end{array}$ \\
\hline Productivity & $\begin{array}{r}0,0119 * * * \\
0,0005\end{array}$ & $\begin{array}{r}0,0041^{* * *} \\
0,0005\end{array}$ & $\begin{array}{r}0,0219 * * * \\
0,0016\end{array}$ & $\begin{array}{r}0,0347^{* * *} \\
0,0041\end{array}$ & $\begin{array}{r}0,0017^{* * *} \\
0,0007\end{array}$ & $\begin{array}{r}0,0083^{* * *} \\
0,0015\end{array}$ & $\begin{array}{r}0,0034^{* * *} \\
0,0008\end{array}$ & $\begin{array}{l}0,0067 \\
0,0075\end{array}$ & $\begin{array}{r}0,0071^{* * *} \\
0,0015\end{array}$ & $\begin{array}{l}0,0039 \\
0,0078\end{array}$ \\
\hline Share of Foreign Ownership & $\begin{array}{r}0,0833^{* * *} \\
0,0031\end{array}$ & $\begin{array}{r}0,0293 * * * \\
0,0036\end{array}$ & $\begin{array}{r}0,1167 * * * \\
0,0077\end{array}$ & $\begin{array}{r}0,2353^{* * *} \\
0,0294\end{array}$ & $\begin{array}{r}0,0213^{* * *} \\
0,0066\end{array}$ & $\begin{array}{r}0,0865^{* * *} \\
0,0086\end{array}$ & $\begin{array}{r}0,0149 * * * \\
0,0040\end{array}$ & $\begin{array}{r}0,1659 * * * \\
0,0373\end{array}$ & $\begin{array}{r}0,1022^{* * *} \\
0,0065\end{array}$ & $\begin{array}{r}0,2134^{* * *} \\
0,0333\end{array}$ \\
\hline Real Exchange Rate & $\begin{array}{r}-0,0001 \\
0,0001\end{array}$ & $\begin{array}{r}0,0002^{* * *} \\
0,0001\end{array}$ & $\begin{array}{r}-0,0014^{* * *} \\
0,0004\end{array}$ & $\begin{array}{r}-0,0017^{*} \\
0,0010\end{array}$ & $\begin{array}{r}-0,0002 \\
0,0002\end{array}$ & $\begin{array}{l}0,0002 \\
0,0004\end{array}$ & $\begin{array}{l}0,0001 \\
0,0001\end{array}$ & $\begin{array}{r}-0,0033 \\
0,0025\end{array}$ & $\begin{array}{l}0,0001 \\
0,0004\end{array}$ & $\begin{array}{r}-0,0021 \\
0,0020\end{array}$ \\
\hline Dummy for Crisis & $\begin{array}{r}-0,0674^{* * *} \\
0,0019\end{array}$ & $\begin{array}{r}-0,0154^{* * *} \\
0,0018\end{array}$ & $\begin{array}{r}-0,1041^{* * *} \\
0,0045\end{array}$ & $\begin{array}{r}-0,3188 * * * \\
0,0102\end{array}$ & $\begin{array}{r}-0,0100 * * * \\
0,0033\end{array}$ & $\begin{array}{r}-0,0648 * * * \\
0,0053\end{array}$ & $\begin{array}{r}-0,0085^{* * *} \\
0,0021\end{array}$ & $\begin{array}{r}-0,1893^{* * *} \\
0,0299\end{array}$ & $\begin{array}{r}-0,0641^{* * *} \\
0,0055\end{array}$ & $\begin{array}{r}-0,2216^{* * *} \\
0,0243\end{array}$ \\
\hline $\mathrm{N}$ & 31734 & 7812 & 7585 & 4744 & 1381 & 3790 & 2888 & 272 & 3618 & 820 \\
\hline Log likelihood & -44314 & -7914 & -11210 & 8862 & -1135 & -5738 & -1876 & -530 & -4401 & -1150 \\
\hline \multicolumn{11}{|c|}{$\begin{array}{l}\text { Catatan: } \\
\text { Angka bergaris miring adalah standard error estimasi } \\
* * *, * * * * \text { adalah signifikan pada level } 1 \%, 5 \% \text { dan } 10 \% \text {. } \\
\text { ISIC: } \\
\text { (31) Makanan, minuman dan tembakau; (32) Tekstil, garmen dan kulit; (33) Kayu, bambu, rotan, willow termasuk perabotan; } \\
\text { (34) Kertas dan produk kertas, percetakan dan publikasi; (35) Produk kimia, minyak, batubara, karet dan plastik; } \\
\text { (36) Produk mineral non-logam, non-minyak, non-batubara; (37) Logam dasar; } \\
\text { (38) Produk logam buatan, mesin dan peralatan; (39) Industri manufaktur lain }\end{array}$} \\
\hline
\end{tabular}

\section{VI.2 Proporsi Output yang Diekspor}

Dampak karakteristik perusahaan terhadap keputusan ekspor tidak sama dengan dampaknya terhadap jumlah produksi yang diekspor (Tabel V.7). Hasil estimasi menunjukkan bahwa perusahaan dengan produktivitas yang lebih besar sangat cenderung memiliki proporsi output ekspor yang lebih rendah. Serupa dengan itu, perusahaan dengan kepemilikan saham asing yang lebih besar sangat cenderung memiliki proporsi output ekspor yang lebih rendah. 
Serupa dengan dampak terhadap keputusan untuk melakukan ekspor, ada pula persistensi dalam jumlah ekspor. Proporsi output yang diekspor yang lebih tinggi satu persen pada tahun tertentu secara signifikan meningkatkan proporsi output yang diekspor pada tahun berikutnya senilai 0,19 persen. Dampak gaji terhadap proporsi output yang diekspor juga positif. Peningkatan gaji sebesar satu persen menyebabkan kenaikan proporsi output yang diekspor sebesar 0,34 persen.

Dengan melihat dampak nilai tukar riil, hasilnya menunjukkan bahwa, perubahan dalam nilai tukar riil berdampak signifikan terhadap proporsi jumlah output yang diekspor. Apresiasi nilai tukar riil sebesar satu persen secara signifikan menurunkan proporsi output yang diekspor sejumlah 0,12 persen. Serupa dengan dampak krisis Asia 1997/1998 terhadap ekspor, krisis juga secara signifikan menurunkan proporsi output barang yang diekspor, dimana proporsinya turun sebesar 17,5 persen.

Terkait proporsi output yang diekspor dalam industri, hasil estimasi menunjukkan bahwa, kecuali untuk industri logam dasar, ada persistensi dalam proporsi output yang diekspor. Di hampir semua industri, harga produk juga berdampak positif terhadap proporsi output yang diekspor. Meskipun harga produk tidak berdampak signifikan terhadap proporsi output yang diekspor di industri lain, namun hal ini berdampak negatif terhadap industri kayu dan perabotan.

Kepemilikan saham asing berdampak negatif bagi sebagian besar industri, namun memiliki dampak positif pada industri kertas dan produk kertas. Di sisi lain, kepemilikan saham asing tidak berdampak signifikan terhadap proporsi jumlah output yang diekspor pada industri kimia, logam dasar dan industri lain.

Dampak jumlah pegawai produksi terhadap proporsi ekspor cukup bervariasi, dimana di beberapa industri hal ini memiliki dampak positif sementara di industri lain berdampak negatif. Jika kita melihat dampak produktivitas, produktivitas tidak berdampak signifikan di sebagian besar industri. Dampak produktivitas sangat negatif hanya pada industri tekstil, kayu, dan industri lain.

Apresiasi nilai tukar riil cenderung menurunkan proporsi output yang ekspor di industri yang secara intensif membutuhkan sumber daya alam. Pengecualiannya adalah bahwa proporsi output yang ekspor di industri makanan sangat dipengaruhi oleh perubahan nilai tukar riil. Di sisi lain, hasil estimasi menunjukkan bahwa nilai tukar riil tidak berdampak signifikan terhadap proporsi ekspor pada industri-industri padat modal (capital intensive). 


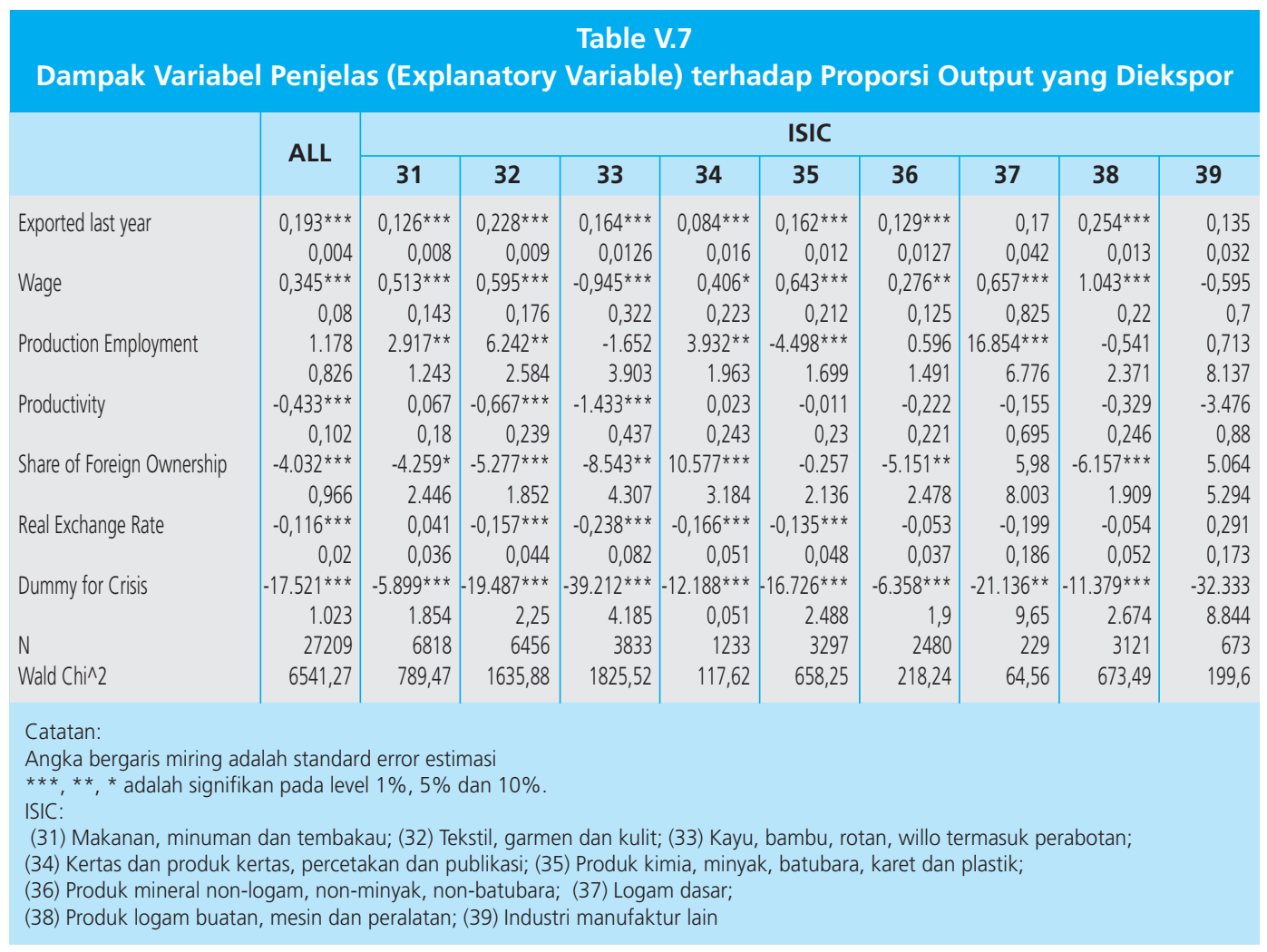

\section{V.7. KESIMPULAN}

Makalah ini menyajikan bukti empiris tentang perilaku ekspor dari perusahaan-perusahaan manufaktur di Indonesia. Untuk tujuan itu kami menggunakan data perusahaan dari survei terhadap industri manufaktur menengah dan besar di Indonesia selama periode 1990-2000. Pertama, kami mengkaji faktor-faktor yang menentukan keputusan perusahaan untuk melakukan ekspor. Hasil estimasi menunjukkan bahwa ada persistensi dalam keputusan perusahaan untuk melakukan ekspor. Selain itu, gaji yang lebih besar, jumlah pegawai produksi yang lebih banyak, produktivitas yang lebih tinggi dan kepemilikan saham asing yang lebih tinggi menyebabkan probabilitas perusahaan untuk melakukan ekspor menjadi lebih tinggi. Di sisi lain, nilai tukar riil tidak berdampak signifikan terhadap probabilitas ekspor.

Kedua, selain mengkaji faktor-faktor yang menentukan keputusan perusahaan untuk melakukan ekspor, kami juga mengkaji faktor-faktor yang menentukan proporsi output yang diekspor. Serupa dengan keputusan untuk melakukan ekspor, proporsi output yang diekspor juga menunjukkan suatu persistensi. Disamping itu, meskipun gaji yang lebih besar menyebabkan 
proporsi ekspor yang lebih tinggi, namun produktivitas dan kepemilikan saham asing yang lebih tinggi menyebabkan proporsi ekspor yang lebih rendah. Selain itu, apresiasi nilai tukar riil menyebabkan proporsi ekspor lebih tinggi dengan magnitude yang sangat kecil.

Terakhir, kami juga melihat perilaku ekspor di seluruh industri, dan hasil estimasi menunjukkan bahwa ada persamaan dan perbedaan perilaku ekspor di dalam industri, baik dalam hal keputusan untuk melakukan ekspor maupun proporsi output barang yang diekspor. Kecuali pada industri logam dasar dimana tidak ada persistensi dalam proporsi output yang diekspor, semua industri menunjukkan persistensi dalam keputusan untuk melakukan ekspor serta dalam proporsi output yang diekspor. Selain itu, kepemilikan saham asing yang lebih tinggi juga secara signifikan menaikkan probabilitas ekspor suatu perusahaan. Di sisi lain, dampak nilai tukar riil bervariasi dalam industri ini, hanya industri-industri tertentu yang terkena dampaknya secara signifikan.

Fakta bahwa ada persistensi dalam status ekspor menunjukkan bahwa untuk memasuki pasar ekspor, perusahaan harus menanggung sunk cost. Ini berarti, untuk memajukan ekspor manufaktur, pihak berwenang memiliki ruang untuk melakukan intervensi dengan, misalnya, memberikan insentif fiskal atau membantu perusahaan dalam penetrasi pasar asing. Di sisi lain, meskipun kebijakan nilai tukar riil membantu mendukung jumlah ekspor perusahaan, namun hal ini nampaknya tidak membantu meningkatkan probabilitas perusahaan untuk melakukan ekspor. 


\section{DAFTAR PUSTAKA}

Aitken, Brian, Gordon H. Hanson, and Ann E. Harrison. (1997). "Spillovers, Foreign Investment and Export Behavior." Journal of International Economics, Vol. 43 (1-2), pp. 103-132.

Arnold, Jens M., and Katrin Hussinger. (2005). "Export Behavior and Firm Productivity in German Manufacturing: a Firm-Level Analysis." Review of World Economics, Vol. 141(2) Álvarez, ROberto and Ricardo A. López, (2008). "Entry and Exit in International Markets: Evidence from Chilean Data," Review of International Economics, Vol.16, No.4, pp. 692-708.

Bernard, Andrew B. and J.B. Jensen. (2004). "Why Some Firms Export," The Review of Economics and Statistics, Vol. 86, No. 2.

Castellini, Davide, Saso Polanec, and Ricardo A. López. (2007). "Exports and Productivity Comparable Evidence for 14 Countries," World Bank's Policy Research Working Paper, No. 4418.

Das, Sanghamitra, Roberts, Mark J., and Tybout James R. (2001). "Market Entry Costs, Producer Heterogeneity, and Exports Dynamics." NBER Working Paper, No. 8629.

Wagner, Joachim. (2007). "Exports and Productivity: A Survey of the Evidence from Firm Level Data." The World Economy 30, 1, pp.60-82. 
halaman ini sengaja dikosongkan 